\title{
Anaerobic co-digestion of the organic fraction of municipal solid waste with
}

several pure organic co-substrates

Sergio Ponsá, Teresa Gea and Antoni Sánchez*

Composting Research Group

Department of Chemical Engineering

Escola d'Enginyeria

Universitat Autònoma de Barcelona

Bellaterra (Cerdanyola del Vallès, 08193-Barcelona, Spain)

* Corresponding author:

Antoni Sánchez

Tel.: (34) 935811019

Fax: (34) 935812013

E-mail: antoni.sanchez@uab.cat

Pre-print of: Ponsá, S.; Gea, T. and Sánchez, A. "Anaerobic co-digestion of the organic fraction of municipal solid waste with several pure organic cosubstrates" in Biosystems engineering (Ed. Elsevier), vol. 108, issue 4 (April 2011), p. 352-360.

The final version is available at DOI 10.1016/j.biosystemseng.2011.01.007 


\begin{abstract}
A strategy to improve the operation of working anaerobic digesters treating the organic fraction of municipal solid wastes (OFMSW) to increase the biogas production is studied. It consists of increasing the organic loading rate of the digesters by adding extra organic matter from some problematic organic wastes. Vegetable oil, animal fats, cellulose and protein were used as pure co-substrates and the co-digestion anaerobic process was analysed in terms of the ultimate methane production, the methane production rate and the hydraulic residence time. The analysis of methane or biogas production led to different conclusions when expressing this parameter on a volatile solids basis or on a reactor volume basis. The need for a combined analysis is highlighted. In addition a new model to predict the biodegradability rate and evaluating the organic matter fraction susceptible to biodegradation was developed and proved to be suitable for assessing anaerobic digestion processes. All four co-substrates used led to some operative improvements. Vegetable oil is the most suitable co-substrate to be anaerobically digested with the OFMSW since all the parameters evaluated were greatly improved compared to the OFMSW digestion.
\end{abstract}

Keywords: anaerobic co-digestion; biogas; organic fraction of municipal solid waste; organic wastes; methane production; kinetic model. 


\section{Nomenclature}

\begin{tabular}{|c|c|c|}
\hline BMP & Biological methane potential & $1\left[\mathrm{CH}_{4}\right] \mathrm{kg}^{-1}[\mathrm{VS}]$ (Normal conditions) \\
\hline $\mathrm{BOC}$ & Biodegradable organic carbon & $\% \mathrm{db}$ (dry basis) or TOC ( $\mathrm{g}$ ) basis \\
\hline $\mathrm{C}$ & Carbon & \\
\hline $\mathrm{C} / \mathrm{N}$ & Carbon to nitrogen ratio & \\
\hline $\mathrm{CW}$ & Cellulose wastes & \\
\hline $\mathrm{VO}$ & Vegetable oil & \\
\hline $\mathrm{AF}$ & Animal fat & \\
\hline $\mathrm{CH}_{4}$ & Methane & \\
\hline $\mathrm{C}_{\mathrm{I}}$ & Inert fraction & $\%$ \\
\hline $\mathrm{CO}_{2}$ & Carbon dioxide & \\
\hline $\mathrm{C}_{\mathrm{R}}$ & Rapidly mineralisable fraction & $\%$ \\
\hline $\mathrm{C}_{\mathrm{S}}$ & Slowly mineralisable fraction & $\%$ \\
\hline $\mathrm{C}_{\mathrm{W}}$ & Remaining carbon in the sample & $\%$ \\
\hline DM & Dry matter & $\%$ \\
\hline $\mathrm{GB}_{21}$ & Cumulative biogas production in 21 days & 1 [biogas] $\mathrm{kg}^{-1}[\mathrm{TS}]$ (Normal conditions) \\
\hline $\mathrm{GB}_{\mathrm{n}}$ & Cumulative biogas production in $\mathrm{n}$ days & 1 [biogas] $\mathrm{kg}^{-1}$ [TS] (Normal conditions) \\
\hline HRT & Hydraulic retention time & day \\
\hline $\mathrm{k}_{\mathrm{R}}$ & Rapid rate constants & \\
\hline $\mathrm{k}_{\mathrm{S}}$ & Slow rate constants & day $^{-1}$ \\
\hline LCFA & Long-chain fatty acic & \\
\hline M & Cumulative BMP & $1\left[\mathrm{CH}_{4}\right] \mathrm{kg}^{-1}[\mathrm{VS}]$ (Normal conditions) \\
\hline MSW & Municipal solid waste & \\
\hline $\mathrm{N}$ & Nitrogen & \\
\hline OFMSW & Organic fraction of municipal solid waste & \\
\hline $\mathrm{OM}$ & Organic matter content & $\%, \mathrm{db}$ \\
\hline IOW & Industrial organic wastes & \\
\hline $\mathrm{P}$ & Maximum methane potential & $1\left[\mathrm{CH}_{4}\right] \mathrm{kg}^{-1}[\mathrm{VS}]$ (Normal conditions) \\
\hline $\mathrm{P}^{\prime}$ & Specific maximum methane potential & $1\left[\mathrm{CH}_{4}\right] 1^{-1}$ [reactor] (Normal conditions) \\
\hline $\mathrm{R}_{\max }$ & Maximum methane production rate & $1\left[\mathrm{CH}_{4}\right] \mathrm{kg}^{-1}[\mathrm{VS}] \mathrm{day}^{-1}$ (Normal conditions) \\
\hline $\mathrm{R}_{\text {max }}^{\prime}$ & Specific maximum methane production rate & $1\left[\mathrm{CH}_{4}\right] \mathrm{l}^{-1}$ day $^{-1}$ \\
\hline $\mathrm{T}$ & Time & hour or day \\
\hline TOC & Total organic carbon & $\%, \mathrm{db}$ \\
\hline UMP & Ultimate methane production & $1\left[\mathrm{CH}_{4}\right] \mathrm{kg}^{-1}[\mathrm{VS}]_{\text {loaded }}$ \\
\hline UMP' & Specific methane production & $1\left[\mathrm{CH}_{4}\right] \mathrm{l}^{-1}$ [reactor $]$ (Normal conditions) \\
\hline VS & Volatile solids & $\%, \mathrm{db}$ \\
\hline $\mathrm{VS}_{\text {loaded }}$ & $\begin{array}{l}\text { Loaded volatile solids (considering only } \\
\text { substrates but not VS corresponding to } \\
\text { inoculum) }\end{array}$ & $\%, \mathrm{db}$ \\
\hline$\lambda$ & Lag phase & day \\
\hline
\end{tabular}




\section{Introduction}

Biogas technologies (European Commission, 2009; 2006; Swedish Institute of Agricultural and Environmental Engineering, 2006; Jansen, 2003) are an attractive and well established alternative that allows the production of energy while processing different organic wastes or biomass and obtaining a solid product that can be used as an organic fertiliser or conditioner (Pain et al., 1988; Lema and Omil, 2001; McCarty, 2001; Lettinga, 2001; Murto et al., 2001; Neves et al., 2006; Neves et al., 2009; European Commission, 2001). In addition, the Landfill Directive 1999/31/EC (article 5) together with the Working Document on Biological Treatment of Biowaste $2^{\text {nd }}$ draft (European Commission, 2001) introduced very challenging targets for the reduction of biodegradable waste to landfill some years ago. In consequence, at present there are a large number of anaerobic digestion facilities treating different kinds of organic wastes such as municipal solid waste (MSW), source-separated organic fraction of municipal solid waste (OFMSW, mainly food and yard wastes), manure, sewage sludge and different industrial organic wastes (IOW).

However, there are some poorly biodegradable IOW that cannot be digested alone due to their characteristics, for example, low solubility or unbalanced carbon-tonitrogen $(\mathrm{C} / \mathrm{N})$ ratio. Nevertheless, when mixed with other complementary wastes, the mixture becomes suitable for anaerobic co-digestion (Alatriste-Mondragón et al., 2006). There is abundant literature about co-digestion processes, such as co-digestion of the OFMSW and agricultural residues (Converti et al., 1997; Kübler et al., 2000), organic wastes and sewage sludge (Neves et al., 2009; Fernández et al., 2005; Zhang et al., 2008) or more specific wastes (Buendía et al., 2009; Bouallagui et al., 2009).

A new strategy to be implemented in already operating plants could be the combined treatment of different kinds of IOW with OFMSW. Thus, on the one hand, a 
new waste would acquire value for use in working digesters, whilst avoiding the need for new investment. On the other hand, energy would be obtained. The most common problematic organic wastes produced by industry or municipalities are those that are rich in lipids, cellulose and proteins.

Lipids are characterised either as fats, oils or greases, coming mainly from food wastes and some industrial wastewaters, such as those from slaughterhouses, dairies or fat refineries (Li et al., 2002). Lipids are attractive for biogas production since they are reduced organic materials with a high theoretical methane potential. However, they also present several problems such as inhibition of methanogenic bacteria and adsorption onto biomass that can cause sludge flotation and washout (Neves et al., 2009).

Cellulose wastes (CW) come mainly from paper and cardboard industries (mostly composed of cellulose, hemicellulose and lignin) or from textile industries. CW are also part of the bulk MSW that is not source-separated, which could be added to the organic waste flow again in order to be anaerobically treated. $\mathrm{CW}$ have a $\mathrm{C} / \mathrm{N}$ ratio ranging from 173:1 to greater than 1000:1, while the suggested optimum $\mathrm{C} / \mathrm{N}$ ratio for anaerobic digestion is in the range of 20:1 to 30:1 (Zhang et al., 2008). Therefore, mixing CW with the OFMSW can provide suitable nutrients for the combined codigestion (Zhang et al., 2008).

Wastes with high protein content and consequent high nitrogen content come mainly from meat industries, slaughterhouses and farms (slurry and manure). Since these wastes have a high organic content, high biological oxygen demand and low $\mathrm{C} / \mathrm{N}$ ratio, anaerobic co-digestion with the OFMSW or sludge is recommended for their treatment (Buendía et al., 2009). In addition, large ammonia concentrations in animal wastes are found to inhibit anaerobic treatments (Nielsen et al., 2008). This problem is 
further accentuated for protein-rich wastes, for which the ammonia concentration significantly increases during their fermentation (Chen et al., 2008).

To the authors' knowledge, there is scarce information about high organic load co-digestion of lipids, cellulose and protein as pure co-substrates for the OFMSW and its assessment and possible implementation in working digesters. In fact, most industrial co-digestion plants treat the OFMSW together (in a relative small percentage) with sewage sludge (Rintala and Jarvinen, 1996; Mata-Álvarez, 2000). In addition, there is a scarce industrial application of co-digestion (Mata-Álvarez, 2000), and most of the studies published are difficult to apply, and consequently only $7 \%$ of the overall anaerobic digestion of the OFMSW capacity is at present co-digested. The aim of this work is to study the feasibility of the co-digestion of the OFMSW with different kinds of pure organic co-substrates such as vegetable oil (VO), animal fat (AF), cellulose and peptone (protein) and to assess the possibilities of implementing this co-digestion

process in already working plants. This can be considered as a necessary step prior to the assessment of co-digestion with real substrates that may have more complex and diverse compositions.

\section{Materials and Methods}

\subsection{Waste sources and inoculum characteristics}

Main properties of the OFMSW, inoculum and co-substrates used are presented in Table 1. The OFMSW samples were obtained from a Mechanical-Biological Treatment (MBT) plant (Barcelona, Spain) that treats mixed MSW and OFMSW in two separated lines, with a total capacity of 240,000 tons of waste per year. The OFMSW samples used were taken from the plant after mechanical pre-treatment and prior to the anaerobic digestion process. This material, essentially free of impurities, is shredded to 
20-30 $\mathrm{mm}$ and fed to the digester in the plant. A representative sample (approximately $40 \mathrm{~kg}$ ) was obtained by mixing four subsamples of about $10 \mathrm{~kg}$ each, taken from different points of the bulk material. This sample was used for biogas and methane production tests and other analyses.

The four co-substrates used were: (i) commercial vegetable (coconut) oil; (ii) animal fat (Trg Debo Fancy, KAO Corporation S.A., Spain); iii) cellulose (cellulose powder, 20 micron, Sigma-Aldrich); and protein (bacteriological peptone, Oxoid, total nitrogen 14\%). An amount of the corresponding co-substrate to $20 \%$ (dry basis) of the OFMSW was added to obtain the target mixtures, which were intended to achieve $20 \%$ increase in the loading rate. Vegetable and animal fats were additionally characterised in terms of their long chain fatty acids. VO is mainly composed of lauric acid (45.5\%), myristic acid (18.5\%), palmitic acid (10.4\%) and oleic acid (8.7\%). AF is mainly composed of oleic acid (38.0\%), palmitic acid (30.0\%) and stearic acid (17.0\%).

The inoculum for anaerobic digestion was collected from the plant anaerobic digester treating OFMSW $\left(4500 \mathrm{~m}^{3}\right.$ capacity, working temperature $37^{\circ} \mathrm{C}$ and hydraulic retention time, HRT, 21 days). The reactor was continuously fed with a mixture of OFMSW:recirculated sludge in a ratio 1:2 (dry basis). The anaerobic inoculum was kept at $37^{\circ} \mathrm{C}$ during two weeks to remove any remaining easily biodegradable fraction.

\subsection{Biological methane production}

To analyse the biogas and methane production of the different samples, an analytical method was set up by adapting the procedure described by the German Institute for Standardization (Federal Government of Germany, 2001). This standard procedure provides the parameter $\mathrm{GB}_{21}$ expressed as normal litres of biogas (temperature: $273 \mathrm{~K}$ and pressure 1.01325 bar) produced per $\mathrm{kg}$ of total solids $\left(\mathrm{kg}^{-1}\right.$ 
[TS]) during 21 days. In the developed test, biogas production was monitored at different times and the test was finished when no significant biogas production was observed (after 135 days). Thus, the parameter GBn was the biogas production obtained for $\mathrm{n}$ days of analysis. Results were expressed both as normal litres of biogas produced per $\mathrm{kg}$ of dry matter and per $\mathrm{kg}$ of volatile solids $\left(\mathrm{kg}^{-1}\right.$ [VS]). The ratio of substrate to inoculum used in the industrial anaerobic digester (1:2 OFMSW to inoculum d.b.), was used in all the experiments involving the use of co-substrates and an extra $20 \%$ of dry matter was added through co-substrate addition. Accordingly, the resulting ratio in the co-digestion experiments was a mixture 1:2:0.2 OFMSW:inoculum:co-substrate (dry basis).

The mixtures were incubated in a temperature-controlled room at $37^{\circ} \mathrm{C}$ in sealed aluminium bottles with a working volume of 11 . Before each experiment, the bottles were purged with nitrogen gas to ensure anaerobic conditions. The bottles had a ball valve that was connected to a digital manometer (SMC model ZSE30, Japan) to measure biogas pressure. The bulk density of the mixture was previously determined (in triplicate) to calculate the headspace volume of the bottles, which was assumed constant during the experiment. During the test, the bottles were shaken once a day. Biogas production was calculated according to the ideal gas law from the pressure measured in the bottle and considering the headspace volume previously measured. To avoid excessive pressure in the bottle, the biogas produced was purged periodically (typically 25-30 times during the experiment), so that the pressure never exceeded 2 bar. This should minimise the possible solubilisation of carbon dioxide since methane is hardly soluble in aqueous media. As a result, the final biogas production over a long period should hardly be affected. 
All biogas production tests were carried out in triplicate (three different bottles for each sample). The results are expressed as an average with standard deviation. The typical deviation found in triplicate samples was in the range of $5-15 \%$. If one of the reactors presented a deviation greater than $20 \%$, it was discarded from the biogas potential calculation, as described in the procedure of the Federal Government of Germany (2001). A biogas production test containing only inoculum and another containing a mixture of inoculum and the OFMSW (substrate:inoculum ratio 1:2 d.b.) were also set up in triplicate to be used as a blank and control test respectively. Specifically the loading rates used were $57.2 \mathrm{~g}$ [TS] $1^{-1}\left(37.4 \mathrm{~g}[\mathrm{VS}] \mathrm{l}^{-1}\right)$ for the blank containing only inoculum, $72.6 \mathrm{~g}[\mathrm{TS}] \mathrm{l}^{-1}\left(49.5 \mathrm{~g}[\mathrm{VS}] \mathrm{l}^{-1}\right)$ for the control, which is the operating loading rate of the industrial digester and close to $87 \mathrm{~g}[\mathrm{TS}] \mathrm{l}^{-1}\left(63.5 \mathrm{~g}\right.$ [VS] $\mathrm{l}^{-}$ ${ }^{1}$ ) for all co-digestion experiments, which represents an increase of $20 \%$ compared to control analysis. The blank is also useful to provide a quantitative measure of inoculum activity. Biogas and methane production from inoculum samples was subtracted from the biogas and methane produced by the waste samples.

Biogas composition was analysed to obtain the biochemical methane production (BMP) using gas chromatography (Perkin-Elmer AutoSystem XL Gas Chromatograph) with a thermal conductivity detector and a Hayesep column $3 \mathrm{~m}$ 1/8" 100/120. The details of biogas analysis can be found elsewhere (Fernández et al., 2005). Typical values of methane percentage in biogas were around 55-70\%, although in specific experiments some values greater than $85 \%$ were measured.

The maximum methane production rate $\left(\mathrm{R}_{\max }\right)$ and lag phase $(\lambda)$ were determined by fitting the modified Gompertz model (Eq. 1) described by Zwietering et al. (1990) and Lay et al. (1998) to the experimental cumulative methane production curves. 


$$
\mathrm{M}=\mathrm{P} \cdot \exp \left\{-\exp \left[\frac{\mathrm{R}_{\text {max }} \cdot e}{\mathrm{P}}(\lambda-\mathrm{t})+1\right]\right\}
$$

where $\mathrm{M}$ is the cumulative BMP $\left(1\left[\mathrm{CH}_{4}\right] \mathrm{kg}^{-1}\right.$ [VS]); $\mathrm{P}$ is the maximum methane potential $\left(1\left[\mathrm{CH}_{4}\right] \mathrm{kg}^{-1}[\mathrm{VS}]\right) ; \mathrm{t}$ is the time (day); $\mathrm{R}_{\max }$ is the maximum methane production rate $\left(1\left[\mathrm{CH}_{4}\right] \mathrm{kg}^{-1}[\mathrm{VS}] \mathrm{day}^{-1}\right)$ and $\lambda$ the lag phase (day).

Matlab v2007a software package (MathWorks Inc., Massachusetts, USA) was used for fitting the value of the model parameters in Equation $1\left(\mathrm{P}, \mathrm{R}_{\max }\right.$ and $\left.\lambda\right)$.

\subsection{Anaerobic biodegradation kinetics modelling}

In order to completely characterise the biodegradable organic matter content of a given waste by means of quantitative measures of the easily and slowly biodegradable organic matter and biodegradation kinetic rate constants, the data of cumulative biogas produced could be fitted to the four models described by Tosun et al. (2008). It has to be noted that Tosun's models were developed to fit data obtained under aerobic conditions and expressed as the percentage of carbon mineralised, calculated as the amount of cumulative $\mathrm{C}-\mathrm{CO}_{2}$ produced, by means of aerobic biodegradation, at a given time on initial total organic carbon (TOC), that is, a biodegradable organic carbon (BOC)/TOC ratio for a given time.

Although Tosun's models are described for use in aerobic biodegradation processes, they could also be used for describing and assessing the anaerobic biodegradation processes. However, Tosun's models present some limitations, of which the most important is consideration of the non-biodegradable organic matter or organic carbon as the slowly biodegradable fraction which obviously leads to only partially reliable results. 
To address the limitations of the first-zero-order and first-first-order models described by Tosun, a new simple model was developed to obtain the three different fractions in which organic matter or carbon can be classified after fitting the data: rapidly biodegradable $\left(\mathrm{C}_{\mathrm{R}}\right)$, slowly biodegradable $\left(\mathrm{C}_{\mathrm{S}}\right)$ and inert fraction $\left(\mathrm{C}_{\mathrm{I}}\right)$. In addition, instead of monitoring the carbon emitted in the form of $\mathrm{CO}_{2}$ which is appropriate when organic matter is aerobically degraded, the carbon contained in the biogas in form of $\mathrm{CO}_{2}$ and $\mathrm{CH}_{4}$ was considered.

If the concept of the Tosun model were to be retained, the mathematical expression would be unable to predict the inert fraction. However, instead of considering the evolution of the carbon emitted, the carbon that still has not been degraded can be also monitored, assuming that the initial TOC corresponds to $100 \%$ of the carbon in the sample and subtracting the carbon emitted from this initial value. The remaining carbon in the sample can be expressed as percentage of the initial TOC.

The mathematical modelling of these data would correspond to the following expression:

$$
C_{W}=C_{R} \exp \left(-k_{R} t\right)+C_{S} \exp \left(-k_{S} t\right)+C_{I}
$$

where $\mathrm{C}_{\mathrm{W}}$ is the remaining carbon in the sample (\%) at time $\mathrm{t}$ (day), $\mathrm{C}_{\mathrm{R}}$ and $\mathrm{C}_{\mathrm{S}}$ are the percentages of rapidly and slowly mineralisable carbon fractions respectively, $\mathrm{C}_{\mathrm{I}}$ is the carbon inert fraction, and $\mathrm{k}_{\mathrm{R}}$ and $\mathrm{k}_{\mathrm{S}}$ are rapid and slow rate constants $\left(\right.$ day $\left.^{-1}\right)$, respectively. This expression consists of two exponential decay terms (first order kinetics) and an independent and constant term.

\subsection{Analytical Methods}

Bulk density, water content, dry matter and organic matter (equivalent to volatile solids) were determined in triplicate according to the standard procedures (The US 
Department of Agriculture and The US Composting Council, 2001). Fat, protein and carbohydrate contents in the initial and final mixtures (after 135 days) were determined according to official methods in Spain (Spanish Ministry of Environment, 2009). No replications were available for these analyses.

\subsection{Statistical methods}

ANOVA tests were performed to compare different treatments. If the ANOVA test resulted in statistically significant differences, Tukey test was performed in pairwise comparisons. A confidence level of $95 \%$ was selected for all statistical comparisons. Statistical tests were conducted with SPSS 15.0.1 (SPSS Inc., USA).

\section{Results and discussion}

\subsection{Methane production yields}

The general characterisation of the inoculum, the OFMSW and co-substrates is shown in Table 1. All the values reported are in agreement with usual characterisations of these materials (Neves et al., 2009; Alatriste-Mondragón et al., 2006; Fernández et al., 2005; Zhang et al., 2008).

Methane cumulative production for all the mixtures was continuously monitored and compared with the control test (OFMSW:inoculum ratio 1:2). As mentioned above, the experiment finished when no significant methane production was detected. As a result the ultimate methane production (UMP), which means the maximum methane potential, was obtained for all the mixtures and expressed as $\left(1\left[\mathrm{CH}_{4}\right] \mathrm{kg}^{-1}\left[\mathrm{VS}_{\text {loaded }}\right]\right)$. Total solids reduction was $4.5 \%$ in the control test and $18 \%$ in the VO experiment while it was practically negligible in the rest of experiments. The inhibition of the methanogenic stage by volatile acid accumulation was not detected in any case as 
demonstrated by methane concentration in biogas that was always higher than $55 \%$. Furthermore ammonia inhibition was not detected when using protein as co-substrate.

The UMP results obtained are reported and compared in Table 2. As observed, UMP of the mixtures increased significantly when using fats as co-substrates $(83.1 \%$ and $33.0 \%$ for $\mathrm{VO}$ and $\mathrm{AF}$ respectively). The opposite trend was observed when using cellulose and protein as co-substrates. It could be concluded that fats could be suitable co-substrates for anaerobic digestion of the OFMS, as they improve VS degradation and increase the biogas production. In addition, considering these results, it could be also stated that cellulose and protein are not suitable for anaerobic co-digestion with the OFMSW.

However, these results need to be carefully interpreted. The amount of total solids was increased $20 \%$ in the co-digestion experiments and consequently the amount of VS treated in the same working volume was also increased. Therefore the use of different units to express the UMP has to be considered. UMP was normalised by the initial substrate VS concentration $\left(\mathrm{kg}\left[\mathrm{VS}_{\text {loaded }}\right] \mathrm{l}^{-1}\right)$ in the mixture corresponding to OFMSW and co-substrates (not considering the VS from inoculum) to obtain the specific volumetric yield. UMP values expressed as $1\left[\mathrm{CH}_{4}\right] 1^{-1}$ (UMP') are also shown in Table 2. In this case, it can be observed that the addition of all four types of cosubstrates significantly increased UMP' by $35.2 \%, 54.4 \%, 176.9 \%$ and $276.2 \%$ for cellulose, protein, AF and VO respectively. These results indicate that the reactor yield in terms of methane (or biogas) produced increases when adding any co-substrate. However, the organic matter (VS) degradation is not always improved and, in consequence, when using cellulose or protein wastes as co-substrates, a more intensive post-treatment for the end-product of anaerobic digestion (e.g. composting) might be necessary. 


\subsection{Kinetic modelling and biological methane potential validation}

Methane cumulative production for vegetable oil and animal fat and for cellulose and protein experiments are shown in Figure 1 and Figure 2 respectively. The control test is also shown in both Figures for comparison.

The Gompertz model was used to describe the methane production in different experiments. Fitting the Gompertz equation to the experimental cumulative methane production is also shown in Figures 1 and 2, and Table 3 shows the Gompertz model parameters (Eq. 1). The values obtained for $\mathrm{P}$ were similar to the UMP experimentally obtained (Table 2). This confirms that the experimental cumulative methane production followed the theoretical trend in all cases, as is also confirmed by the goodness of fit of the Gompertz model to the experimental data ( $\mathrm{p}<0.001$ in all cases).

The lag phase was almost negligible and statistically equivalent for the control test and the cellulose and protein experiments. However, when adding fats as cosubstrates a lag phase of around 9 days was detected (Table 3). This could be explained by the fact that the inoculum used was not acclimatised to the different biochemical nature of fats (Fernández et al., 2005). In continuous experiments or in real digesters, this lag phase would disappear after an inoculum acclimation period. In this case, the overloading of the reactor can be avoided by starting up the reactor with a gradual increase of the co-substrate content in the input flow (Fernández et al., 2005).

$\mathrm{R}_{\max }$, expressed as $1\left[\mathrm{CH}_{4}\right] \mathrm{kg}^{-1}\left[\mathrm{VS}_{\text {loaded }}\right] \mathrm{day}^{-1}$, was statistically higher for control test and protein experiment than for $\mathrm{VO}, \mathrm{AF}$ and cellulose co-digestion experiments, which again highlights the importance of the inoculum acclimation and the effect of increasing the organic load. 
Considering the Gompertz data fitting, it can be noted that the cumulative methane production for the control test and for the cellulose and peptone experiments reached the maximum before 21 days. This is in accordance with the operational HRT of the real digester from which the inoculum was obtained and confirms that it was working at the optimum HRT. However, for fats co-digestion experiments, and assuming that the lag phase would disappear in continuous operation, the maximum methane production would be reached after approximately 60 days of operation, which is similar to that found in other studies with complex wastes (Cuetos et al., 2008). This is related to the different biochemical nature and biodegradability of the co-substrates used, as well as to the higher energy content of fats compared to protein and cellulose (Ruggieri et al., 2008).

Considering the cumulative methane potential at 21 days of operation for all the experiments, interesting conclusions can be obtained. For fat co-digestion experiments 21 days were insufficient to reach the ultimate or maximum methane production. However the $\mathrm{M}$ values obtained at this point were close to $4501\left[\mathrm{CH}_{4}\right] \mathrm{kg}^{-1}\left[\mathrm{VS}_{\text {loaded }}\right]$ for VO, which still represents an improvement over $25 \%$ compared to the control test.

Finally, an individual analysis for each co-substrate used can be done. Considering the above results, it could be established that VO is the most suitable waste that can be used as co-substrate in anaerobic digesters. In addition UMP and UMP' increased $83.1 \%$ and $276.2 \%$ respectively and the cumulative methane potential at 21 days had also increased by $28.6 \%$. Consequently, higher VS degradation was also obtained after 21 and 135 days. Additionally, methane concentration in biogas had always reached $85 \%$ after 25 days while the highest value for the control test was $68 \%$. All these results would indicate that the anaerobic digestion was improved in all aspects. Moreover a previous study demonstrated that VO is an excellent co-substrate 
for a simulated OFMSW when operating under continuous conditions (Fernández et al., 2005) showing no LCFA inhibition or cell washout. In addition LCFA were completely degraded in the process.

When using AF, a different behaviour was observed compared to VO. UMP and UMP' values increased 33.0 and $176.9 \%$ respectively while $\mathrm{R}_{\max }$ decreased $61.1 \%$. Additionally, although the UMP was notably increased, the low methane production rate led to a low cumulative methane production at 21 days $(16.7 \%$ lower than control test). The feasibility of using AF as co-substrate needs to be evaluated in economic terms and considering possible destabilisation due to the presence of fats (Rincón et al., 2008). Higher methane (and biogas) production per unit of digester volume would be obtained when increasing HRT above 21 days, but a lower organic matter stabilisation (degradation) would take place. This means that some other organic matter stabilisation process, such as composting, must be intensively applied to the digested material. In economic terms it would mean that, for a HRT of 21 days, more energy can be obtained per unit volume of reactor while less energy is obtained per $\mathrm{kg}$ of VS loaded, and consequently more energy must be used in other post-treatment to stabilise the organic matter.

Results obtained for cellulose and protein experiments were similar; therefore the same analysis can apply for both. UMP and $\mathrm{R}_{\max }$ values did not increase and the cumulative methane and biogas production at 21 days was 31.3 and $22.9 \%$ lower than control assays for cellulose and protein respectively. Organic matter degradation was also lower, but when results are expressed on a volume basis (UMP'), trends changed completely. UMP' increased 39.9 and $58.2 \%$ for cellulose and protein experiments respectively. Again, these results should be analysed from an economic point of view. 
Higher reactor yields in terms of $1\left[\mathrm{CH}_{4}\right] \mathrm{l}^{-1}$ [reactor] would be obtained while less organic matter would be degraded to biogas.

\subsection{Co-substrates specific degradation}

In order to know the amount of co-substrate that had been degraded in the codigestion experiments, fat, sugars and protein analysis were carried out. The initial and final (after 135 days of experiment) mixtures composition is reported in Table 4 as well as the calculated reduction for each fraction. In this table, the content of sugars, fats and proteins is presented as a percentage. However, the reduction of the three components is calculated considering the total initial and final mass in the reactors (considering total VS reduction).

The results showed that fats were more degraded when using fats as co-substrate since it became the main substrate for anaerobic bacteria to the detriment of sugars or protein. The same behaviour was detected for cellulose experiments but not for protein.

When using VO and AF as co-substrates, fat degradation values were similar. However sugars and protein degradation were much higher for VO experiment. This would explain its higher UMP, UMP' and $\mathrm{R}_{\max }$ values. When using AF as co-substrate, sugar degradation seemed to be inhibited and protein degradation significantly decreased (33\%).

When using cellulose as co-substrate, high degradation of sugars was achieved together with the highest protein degradation. It can be concluded that cellulose is a good co-substrate since it allows the simultaneous anaerobic degradation of the other organic components.

After 135 days, final concentrations in all experiments where similar to that of control assay except for sugars final concentration in AF experiment, as discussed 
above, and protein final concentration in protein experiment (Table 4). In this last case, the low protein biodegradation observed, similar to that of the control, might indicate that this co-substrate was not significantly degraded, although inhibition caused by the excessive presence of volatile fatty acids was observed when treating high organic loads of protein (data not shown).

\subsection{Assessment of biodegradable organic matter fractions through anaerobic} biodegradation kinetics modelling

All data from the co-digestion experiments was fitted to the new model proposed and the results obtained are shown in Table 5 while model fittings and the evolution of $\mathrm{C}_{\mathrm{R}}$ and $\mathrm{C}_{\mathrm{S}}$ are plotted in Figure 3.

It can be seen that this model permits the determination of three carbon or organic matter fractions $\left(\mathrm{C}_{\mathrm{R}}, \mathrm{C}_{\mathrm{S}}\right.$ and $\left.\mathrm{C}_{\mathrm{I}}\right)$ and the two biodegradation rate constants $\left(\mathrm{k}_{\mathrm{R}}\right.$ and $\mathrm{k}_{\mathrm{S}}$ ). This method is more reliable than that proposed by Tosun, since the consideration of non-biodegradable carbon as part of the total organic carbon is unquestionably necessary for a complete waste characterisation. In addition it is also confirmed by the goodness of model fitting ( $\mathrm{p}<0.001$ in all cases) and by the correlation coefficients $\left(\mathrm{R}^{2}>0.98\right.$ in all cases). It has to be mentioned that lag phase data was subtracted from OFMSW:VO and OFMSW:AF co-digestion experiments prior to fitting the data to the new model.

Although not reflected in Table 5, for the OFMSW (control), OFMSW:VO and OFMSW:AF the model proposed gives values for both $\mathrm{C}_{\mathrm{R}}$ and $\mathrm{C}_{\mathrm{S}}$. However, the resultant kinetic constants $\mathrm{k}_{\mathrm{R}}$ and $\mathrm{k}_{\mathrm{S}}$ are exactly the same and consequently the organic matter mathematically included in $C_{R}$ and $C_{S}$ fractions is equivalent. Thus, the biodegradable organic matter contained in the OFMSW can be entirely considered as 
rapidly anaerobically biodegradable, but when the OFMSW is co-digested with VO or $\mathrm{AF}$, the biodegradation kinetic rate decreases significantly (67\% and $80 \%$ respectively) and consequently organic matter is biodegraded more slowly. On the contrary, when the OFMSW is co-digested with cellulose and protein, different kinetic rate constants are obtained for $C_{R}$ and $C_{S}$ with $k_{R}$ values similar to those obtained for the control experiment. Particularly when the OFMSW is co-digested with cellulose, $\mathrm{k}_{\mathrm{R}}$ decreases by $22 \%$ while it is maintained at the same value when it is co-digested with protein.

In spite of this, $C_{S}$ values are really low compared to $C_{R}$ and therefore they can be considered negligible. The biodegradability of the OFMSW and its comparison with co-digestion mixtures can be evaluated when comparing $\mathrm{C}_{\mathrm{R}}$ values and including also $\mathrm{C}_{\mathrm{S}}$ results. In this sense, $\mathrm{C}_{\mathrm{R}}$ ranges from approximately $40 \%$ to $50 \%$ in all the mixtures studied except when adding VO as co-substrate. If VO is co-digested with the OFMSW, $\mathrm{C}_{\mathrm{R}}$ increases up to $63 \%$, what would be in accordance with the results obtained from the Gompertz model. In addition, if comparing the rate of biodegradability after 21 days (equivalent to the HRT of the real digester) with the control results, the values are similar and close to $40 \%$. This would mean that, in both experiments (control and OFMSW:VO) after 21 days of anaerobic biodegradation process, $40 \%$ of the initial TOC would have been converted to biogas. Furthermore, when VO is added the methane content in biogas increases by $25 \%$, which gives an additional economical benefit to the process.

When the OFMSW is co-digested with AF, cellulose or protein waste, the percentage of organic matter converted to biogas is similar $\left(C_{I}\right.$ values range from 50 $55 \%$ ) while the initial loading rate is increased. This would imply, as was also suggested from the Gompertz model results, the need for an intensive post-anaerobic digestion treatment that allows for the required stabilisation of the organic matter. 
Finally, it is important to point out that this model allows for the evaluation of carbon degradation kinetics related to the efficiency of the process in terms of organic matter biodegradation, while the Gompertz model allows for the evaluation of methane production kinetics and therefore a complete economic analysis of the process.

\section{Conclusions}

The main conclusions that can be extracted from this study are:

1) The co-substrates used, vegetable oil, animal fat, cellulose and protein, seem to be adequate for anaerobic co-digestion because all four led to some operative improvements. However the implementation of a real full scale co-digestion process using these co-substrates needs a rigorous economic and technical analysis, allowing for local factors.

2) It has been demonstrated that VO is the most suitable co-substrate for anaerobic digestion with the OFMSW since all the parameters evaluated with the Gompertz model (UMP, UMP', R and R' and total solids reduction) are greatly improved compared to the control experiment. In addition, when assessing the biodegradable organic matter biodegradation, $\mathrm{VO}$ is also the most suitable co-substrate because $\mathrm{C}_{\mathrm{R}}$ is clearly increased while biodegradation rate is maintained close to $40 \%$ after 21 days of process and despite a $20 \%$ increase in the initial loading rate. When individual co-substrate degradations are considered, VO is again the more feasible waste to be used as cosubstrate. The use of the other co-substrates (AF, cellulose and peptone) needs an economic and technical evaluation since they improve some anaerobic digestion aspects, such as ultimate methane production, but their initial production rate is lower than that of the control and rates of biodegradability are not improved. 
3) The experimental data obtained in all the co-digestion experiments was well fitted by a Gompertz model.

4) The way to express a yield in anaerobic digestion, based on reactor volume or volatile solid fed in the reactor, may lead to different observations. Both forms are to be considered when evaluating a new co-substrate in a specific situation.

5) The new model proposed, based on that described by Tosun, can appropriately predict the biodegradable fractions of a sample as well as the biodegradation kinetic rates. In addition the total rate of biodegradation is provided by the model.

6) Future work on the use of co-substrates in anaerobic digestion at industrial scale should be based on real tests at full scale with an accurate operational, economic, logistical and environmental analysis.

\section{Acknowledgments}

Financial support was provided by the Spanish Ministerio de Educación y Ciencia (Project CTM2009-14073-C02-01). 


\section{References}

Alatriste-Mondragón, F., Samer, P., Cox, H., Ahring, B., \& Iranpour R. (2006). Anaerobic codigestion of municipal, farm, and industrial organic wastes: a survey of recent literature. Water Environment Research, 78, 607-636.

Bouallagui, H., Lahdheb, H., Ben Romdan, E., Rachdi, B., \& Hamdi M. (2009). Improvement of fruit and vegetable waste anaerobic digestion performance and stability with co-substrates addition. Journal of Environmental Management, 90, 1844-1849.

Buendía, I.M., Fernández, F.J., Villaseñor, J., \& Rodríguez L. (2009). Feasibility of anaerobic co-digestion as a treatment option of meat industry wastes. Bioresource Technology, 100, 1903-1909.

Chen, Y., Cheng, J.J., \& Creamer K.S. (2008). Inhibition of anaerobic digestion process: a review. Bioresource Technology, 99, 4044-4064.

Converti, A., Drago, F., Ghiazza, G., Borghi M., \& Macchiavello A. (1997). Codigestion of municipal sewage sludges and pre-hydrolysed woody agricultural wastes. Journal of Chemical Technology \& Biotechnology, 69, 231-239.

Cuetos, M.J., Gómez, X., Otero, M., \& Morán, A. (2008). Anaerobic digestion of solid slaughterhouse waste (SHW) at laboratory scale: Influence of co-digestion with the organic fraction of municipal solid waste (OFMSW). Biochemical Engineering Journal, 40, 99-106.

European Commission. (2001). Working document. Biological treatment of biowaste, 2nd draft.

European Commission. Directive 2006/12/EC of the European Parliament and of the Council of 5 April 2006 on waste. Official Journal of the European Union. 
European Commission. Directive 2009/28/EC of the European Parliament and of the Council of 23 April 2009 on the promotion of the use of energy from renewable sources amending and subsequently repealing Directives 2001/77/EC and 2003/30/EC. Official Journal of the European Union.

Federal Government of Germany. Ordinance on environmentally compatible storage of waste from human settlements and on biological waste-treatment facilities of 20 February 2001.

Fernández, A, Sánchez, A., \& Font, X. (2005). Anaerobic co-digestion of a simulated organic fraction of municipal solid wastes and fats of animal and vegetable origin. Biochemical Engineering Journal, 26, 22-28.

Jansen, J.C. (2003). Policy support for renewable energy in the European Union: A review of the regulatory framework and suggestions for adjustment. Document number ECN-C-03-113.

Kübler, H., Hoppenheidt, K., Hirsch,P., Kottmair, A., Nimmrichter, R., Nordsleck, H., Mücke, W., \& Swerev, M. (2000). Full-scale co-digestion of organic waste. Water Science and Technology. 41, 195-202.

Lay, J.J., Li, Y.Y., \& Noike T. (1998). The influence of pH and ammonia concentration on the methane production in high-solids digestion processes. Water Environment Research, 70, 1075-1082.

Lema, J.M., \& Omil, F. (2001). Anaerobic treatment: a key technology for a sustainable management of wastes in Europe. Water Science and Technology. 44, 133-140.

Lettinga, G. (2001). Digestion and degradation, air for life. Water Science and Technology. 44, 157-176. 
Li, Y.Y., Sasaki, H., Yamashita, K., Seki, K., \& Kamigochi, I. (2002). High-rate methane fermentation of lipid-rich food wastes by a high-solids co-digestion process. Water Science and Technology, 45, 143-150.

Mata-Álvarez, J., Macé, S., \& Llabrés, P. (2000). Anaerobic digestion of organic solid wastes. An overview of research achievements and perspectives, Bioresource Technology. 74, 3-16.

McCarty, P.L. (2001). The development of anaerobic treatment and its future. Water Science and Technology, 44, 149-156.

Murto, M., Bjornsson, L., \& Mattiasson, B. (2004). Impact of food industrial waste on anaerobic co-digestion of sewage sludge and pig manure. Journal of Environmental Management, 70, 101-107.

Neves, L., Oliveira, R., \& Alves, M.M. (2006). Anaerobic co-digestion of coffee waste and sewage sludge. Waste Management, 26, 176-181.

Neves, L., Oliveira, R., \& Alves, M.M. (2009). Co-digestion of cow manure, food waste and intermittent input of fat. Bioresource Technology, 100, 1957-1962.

Nielsen, H.B., \& Angelidaki I. (2008). Strategies for optimizing recovery of the biogas process following ammonia inhibition. Bioresource Technology, 99, 7995-8001.

Pain, B.F., Phillips, V., \& West, R. (1988). Mesophilic anaerobic digestion of dairy slurry on a farm scale: energy considerations. Journal of Agricultural Engineering Research 39, 123-135.

Review of European Policies Affecting Implementation of Anaerobic Digestion. (2006). JTI-Swedish Institute of Agricultural and Environmental Engineering.

Rincón, B., Borja, R., González, J.M., Portillo, M.C., \& Sáiz-Jiménez, C. (2008). Influence of organic loading rate and hydraulic retention time on the performance, 
stability and microbial communities of one-stage anaerobic digestion of twophase olive mill solid residue. Biochemical Engineering Journal, 40, 253-261.

Rintala, J.A., \& Jarvinen, K.T. (1996). Full-scale mesophilic anaerobic co-digestion of municipal solid waste and sewage sludge: methane production characteristics. Waste Management Research, 14, 163-170.

Ruggieri, L., Gea, T., Artola, A., \& Sánchez, A. (2008). Influence of co-substrates of different biochemical composition on raw sludge co-composting. Biodegradation, $19,403-415$.

Spanish Ministery of Environment. (2009). Official Analysis Methods. URL: http://www.marm.es (accessed December 2010).

The US Department of Agriculture and The US Composting Council. (2001). Test methods for the examination of composting and compost. Houston, TX: Edaphos International.

Tosun, I., Gönüllü, M.T., Arslankaya, E., \& Günay, A. (2008). Co-composting kinetics of rose processing waste with OFMSW. Bioresource Technology, 99, 6143-6149.

Zhang, P., Zeng, G., Zhang, G., Li, Y., Zhang, B., \& Fan, M. (2008). Anaerobic codigestion of biosolids and organic fraction of municipal solid waste by sequencing batch process. Fuel Processing Technology, 89, 485-489.

Zwietering, M.H., Jongenburger, I., Rombouts, F.M., \& Van't Riet, K. (1990). Modeling of the bacterial growth curve. Applied and Environmental Microbiology, 56, 1875-1881. 


\section{Tables}

Table 1. Characteristics of initial OFMSW, inoculum and co-substrates used in the study.

\begin{tabular}{lllllll}
\hline Parameter & OFMSW & Inoculum & Vegetable oil & Animal fat & Cellulose & Protein \\
\hline Dry matter & 29.0 & 7.0 & $>99$ & $>98$ & $>99$ & $>99$ \\
$(\%)$ & & & & & \\
Organic matter & 77.0 & 65.4 & $>99$ & $>99$ & $>99$ & $>99$ \\
$(\%$ dry basis $)$ & & & & & \\
Fat content & 11.52 & 7.86 & $>99$ & $>99$ & 0.0 & 0.0 \\
$(\%$ dry basis $)$ & & & $<0.02$ & $<0.02$ & 0.0 & 14 \\
N-Kjeldahl & 1.83 & 2.89 & & & \\
$(\%$ dry basis $)$ & & & & & \\
C/N ratio & 14.09 & 37.45 & $>4000$ & $>4000$ & $>4000$ & - \\
\hline
\end{tabular}


Table 2. Ultimate methane potential obtained in co-digestion experiments. For each parameter, values followed by different letters in brackets are statistically different.

\begin{tabular}{lll}
\hline Mixture & UMP $\left(1\left[\mathrm{CH}_{4}\right] \mathrm{kg}^{-1}[\mathrm{VS}]\right)$ & $\mathrm{UMP}^{\prime}\left(1\left[\mathrm{CH}_{4}\right] \mathrm{l}^{-1}\right)$ \\
\hline Control (OFMSW) & $382 \pm 23(\mathrm{a})$ & $5.2 \pm 0.3(\mathrm{a})$ \\
OFMSW:Vegetable Oil & $699 \pm 6(\mathrm{~b})$ & $19.6 \pm 0.2(\mathrm{~b})$ \\
OFMSW:Animal Fat & $508 \pm 16(\mathrm{c})$ & $14.4 \pm 0.5(\mathrm{c})$ \\
OFMSW:Cellulose & $254 \pm 10(\mathrm{~d})$ & $7.0 \pm 0.4(\mathrm{~d})$ \\
OFMSW:Protein & $288 \pm 7(\mathrm{~d})$ & $8.0 \pm 0.2(\mathrm{e})$ \\
\hline
\end{tabular}


Table 3. Summary of the estimated parameters from Gompertz equation for digestion and co-digestion experiments. For each parameter, values followed by different letters in brackets are statistically different.

\begin{tabular}{llll}
\hline Mixture & $\mathrm{P}\left(1\left[\mathrm{CH}_{4}\right] \mathrm{kg}^{-1}[\mathrm{VS}]\right)$ & $\mathrm{R}_{\max }\left(1\left[\mathrm{CH}_{4}\right] \mathrm{kg}^{-1}[\mathrm{VS}] \mathrm{day}^{-1}\right)$ & $\lambda$ (day) \\
\hline Control (OFMSW) & $350 \pm 27(\mathrm{a})$ & $35 \pm 1(\mathrm{a})$ & $0.6 \pm 0.1$ (a) \\
OFMSW:Vegetable Oil & $686 \pm 7(\mathrm{~b})$ & $21.9 \pm 0.7(\mathrm{~b})$ & $8.9 \pm 0.2(\mathrm{~b})$ \\
OFMSW:Animal Fat & $490 \pm 26(\mathrm{c})$ & $14 \pm 1(\mathrm{c})$ & $9.1 \pm 0.1(\mathrm{~b})$ \\
OFMSW:Cellulose & $240 \pm 16(\mathrm{~d})$ & $17 \pm 2(\mathrm{~d})$ & $0.37 \pm 0.05$ (a) \\
OFMSW:Protein & $269 \pm 3(\mathrm{~d})$ & $32.0 \pm 0.7$ (a) & $0.50 \pm 0.07$ (a) \\
\hline
\end{tabular}


Table 4. Co-substrates specific degradation analysis.

\begin{tabular}{|c|c|c|c|c|c|c|c|}
\hline & Initial & ays) & & Final (aft & 135 days) & & Elimin \\
\hline Mixture & $\begin{array}{l}\text { Total } \\
\text { Fats } \\
(\%, \\
\text { ww })^{*}\end{array}$ & $\begin{array}{l}\text { Total } \\
\text { Sugars } \\
(\%, w w)\end{array}$ & $\begin{array}{l}\text { Total } \\
\text { Protein } \\
(\%, w w)\end{array}$ & $\begin{array}{l}\text { Total } \\
\text { Fats } \\
(\%, w w)\end{array}$ & $\begin{array}{l}\text { Total } \\
\text { Sugars } \\
(\%, w w)\end{array}$ & $\begin{array}{l}\text { Total } \\
\text { Protein } \\
(\%, w w)\end{array}$ & $\begin{array}{l}\text { Fats } \\
(\%)\end{array}$ \\
\hline Control (OFMSW) & 0.71 & 0.69 & 4.37 & 0.44 & 0.14 & 4.93 & 40.86 \\
\hline OFMSW:Vegetable Oil & 2.08 & 0.33 & 4.86 & 0.44 & 0.15 & 3.63 & 80.00 \\
\hline OFMSW:Animal Fat & 2.12 & 0.33 & 4.86 & 0.55 & 0.41 & 4.16 & 75.64 \\
\hline OFMSW:Cellulose & 0.70 & 1.71 & 4.86 & 0.54 & 0.14 & 3.42 & 27.72 \\
\hline OFMSW:Protein & 0.70 & 0.33 & 6.24 & 0.55 & 0.18 & 6.24 & 24.65 \\
\hline
\end{tabular}

* ww: wet weight 
Table 5. Kinetic parameters for new model developed. Data are obtained from fitting Equation 2.

\begin{tabular}{lllllll}
\hline & TOC $(\%)$ & $\mathrm{C}_{\mathrm{R}}(\%)$ & $\mathrm{C}_{\mathrm{S}}(\%)$ & $\mathrm{C}_{\mathrm{I}}(\%)$ & $\mathrm{k}_{\mathrm{R}}\left(\right.$ day $\left.^{-1}\right)$ & $\mathrm{k}_{\mathrm{S}}\left(\mathrm{day}^{-1}\right)$ \\
\hline OFMSW & 44.2 & 46.2 & --- & 53.8 & 0.138 & --- \\
(control) & & & & & & \\
OFMSW:VO & 57.5 & 62.6 & --- & 37.4 & 0.045 & --- \\
OFMSW:AF & 58.9 & 49.2 & --- & 50.8 & 0.027 & --- \\
OFMSW:C & 44.3 & 40.6 & 3.4 & 55.9 & 0.107 & 0.009 \\
OFMSW:P & 44.8 & 47.1 & 3.3 & 49.7 & 0.139 & 0.009 \\
\hline
\end{tabular}




\section{Legends to Figures}

Figure 1: Evolution of Cumulative Methane Production during 135 days for Control test $(\bullet)$, Vegetal Oil (VO) (०), Animal Fat (AF) ( $\boldsymbol{\nabla})$ co-digestion experiments and Gompertz model (-).

Figure 2: Evolution of Cumulative Methane Production during 135 days for Control test $(\bullet)$, Cellulose (०), Protein $(\boldsymbol{\nabla})$ co-digestion experiments and Gompertz model (-).

Figure 3: Evolution of carbon remaining in the sample $(\bullet)$, kinetic model-fitting ( - , evolution of $\mathrm{C}_{\mathrm{R}}$ degradation ( - - - ) and evolution of $\mathrm{C}_{\mathrm{S}}$ degradation $(-\cdots-)$. Carbon is expressed as total organic carbon (TOC) 
Figure 1: Ponsá et al.

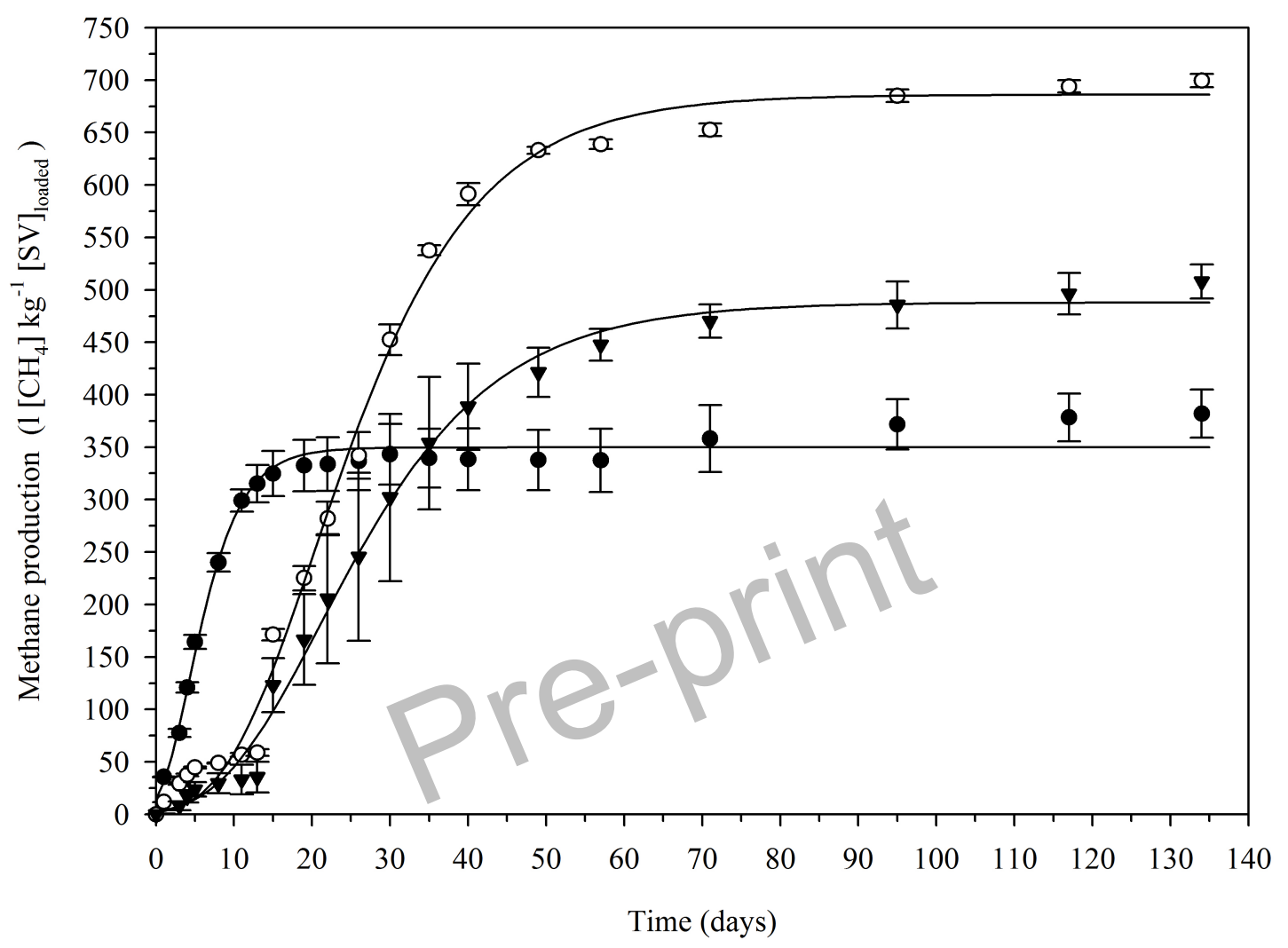


Figure 2: Ponsá et al.

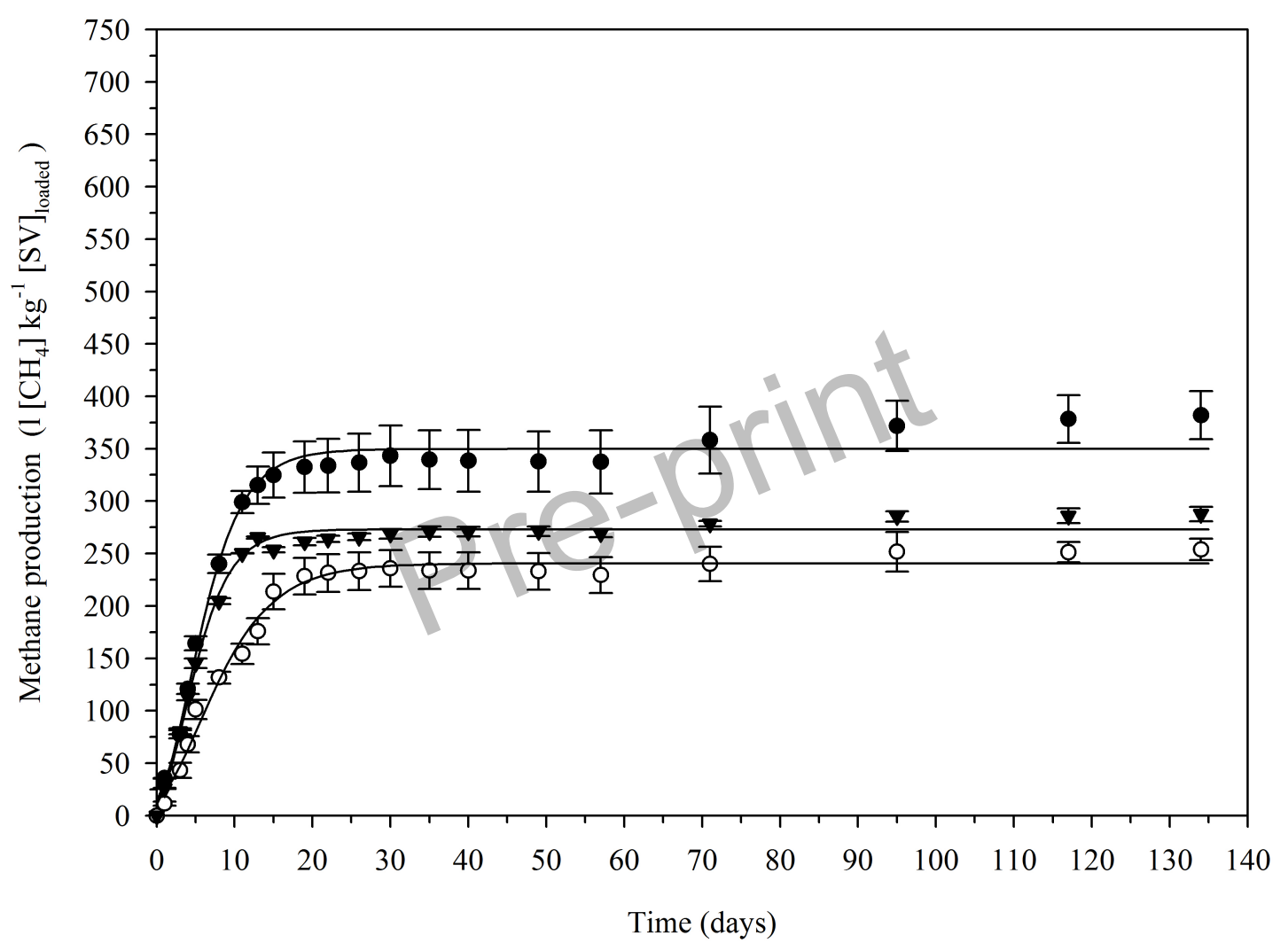


Figure 3: Ponsá et al.
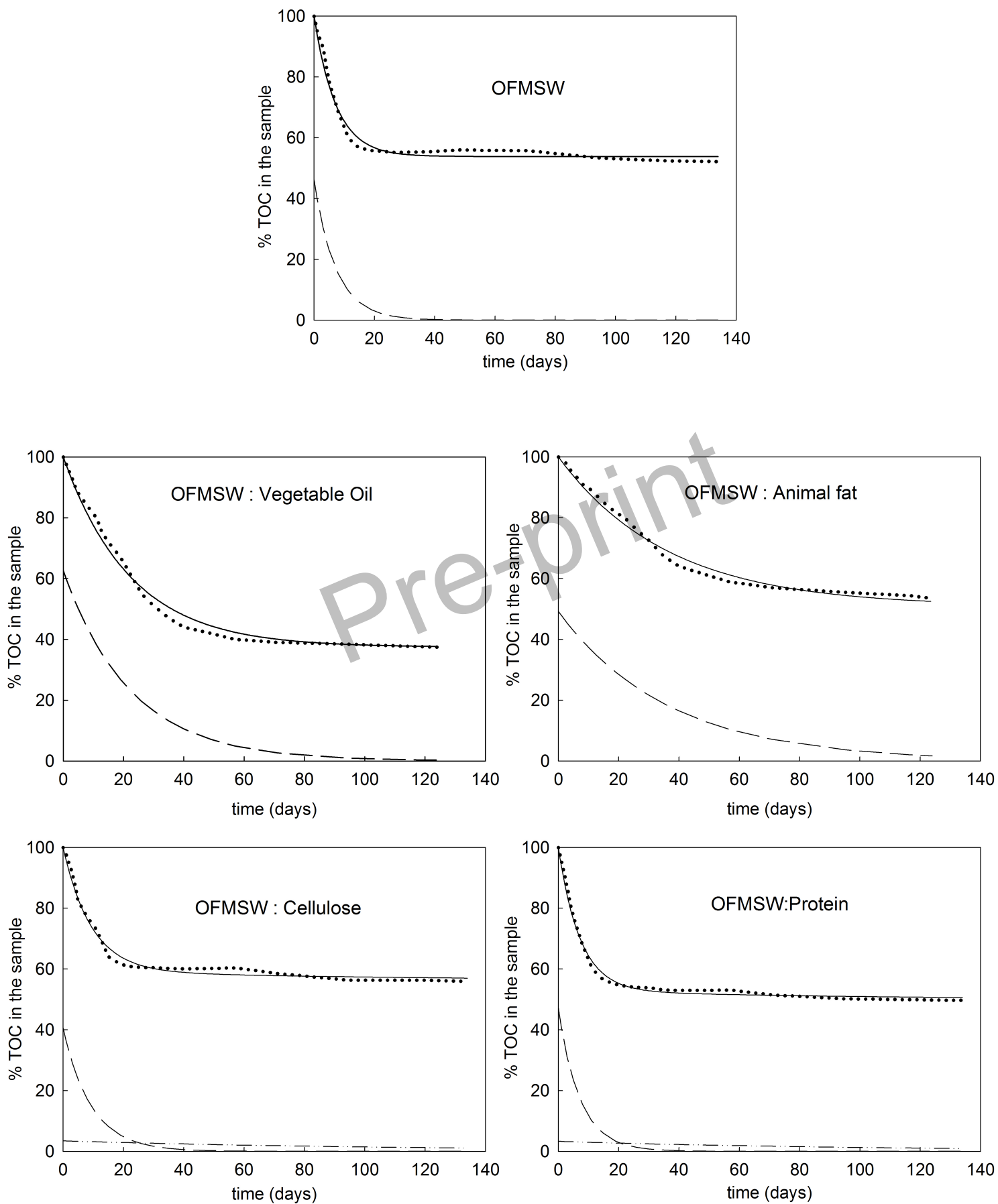